九州大学学術情報リポジトリ

Kyushu University Institutional Repository

\title{
Investigation of Factors Influencing the Choice of Smartphone Banking in Bangladesh
}

Deb, Santus Kumar

Department of Tourism and Hospitality Management, University of Dhaka

Deb, Nibir

Department of Accounting and Information Systems, University of Dhaka

Roy, Showvon

Department of Accounting and Information Systems, University of Dhaka

https://doi.org/10.5109/2349299

出版情報 : Evergreen. 6 (3)，pp. 230-239，2019-09. 九州大学グリーンテクノロジー研究教育センター バージョン：

権利関係 : 


\title{
Investigation of Factors Influencing the Choice of Smartphone Banking in Bangladesh
}

\author{
Santus Kumar Deb ${ }^{1, *}$, Nibir Deb ${ }^{2}$, Showvon Roy ${ }^{2}$ \\ ${ }^{1}$ Department of Tourism and Hospitality Management, University of Dhaka, Bangladesh \\ ${ }^{2}$ Department of Accounting and Information Systems, University of Dhaka, Bangladesh \\ *Author to whom correspondence should be addressed, \\ E-mail: santus@du.ac.bd
}

(Received April 12, 2019; accepted July 12, 2019)

\begin{abstract}
Now a day Smartphone Banking is considered as an essential part of a knowledge-based economy. This Manuscript theme is to examine the factors that are influencing the choice of Smartphone banking services. A conceptual model is designed to provide valuable insight and investigate various choice requirements to be considered in Smartphone banking services. The study focuses on the quantitative approach as it's fully based on empirical data collected from structural questionnaires and background information from the previous study with various secondary sources. In this examine, a statistical approach like regression analysis is used to identify and measure the influences of choice factors of Smartphone Banking services. The study found that Privacy and Security, Perceived Financial Cost, Convenience, and Network/Internet of Smartphone substantially influence of Smartphone services choice to the clients. Researchers suggested that perceived ease of use, usefulness and customers' needs are considered additional factors of Smartphone banking services adoption in forthcoming.
\end{abstract}

Keywords: adoption, customers' expectation, knowledge economy, smartphone banking services.

\section{Introduction}

Smartphone innovation is a generally new invention that is quickly developing and bit by bit affecting customers' behavior, their day by day workouts, social exercises, the mobile business, activities of business, marketing, education, health-related services and further services (Alwahaishi and Snášel, 2013'); Carayannis and Clark, 20112); and Rohm et.al 2012 ${ }^{3)}$ ). Smartphone innovation offers the potential as a way to improve effectiveness, profitability, lessen costs, improve clients' fulfillment and upgrade their involvement of related industries including mobile industry, health-related services, fiscal, online business, teaching, amusement, the travel industry and that's just the beginning (Chun et

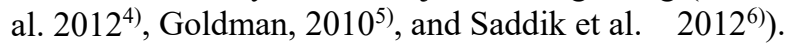

New terminology smartphone is utilized to describe a mobile phone with a unique Personal Computer (PC) empowered highlights. The rivalry between numerous companies, developers and suppliers in the smartphone business is still extremely serious. Several gadget makers, for example, Apple, Samsung, and LG are contending to acquire part of the overall industry and get more consumers. In assembling the operating framework of the smartphone in which worldwide challenge is as yet savage among numerous competitors including Apple, Android, Microsoft, Symbian, Bada, and RIM (Kenney, and Pon, 20117)). Smartphone users are viewed as a critical key factor to proceed with a fruitful development for the smartphone innovation and the majority of its partners (Dai, and Palvi, 20098).

Smartphone banking indicates proper management of monetary transactions by a Smartphone such as investigations of balance, transaction records, and payments, currency allocations. Recently, banks initiated Smartphone banking services to stipulate superior customer services through modern technology (Kim et al. $2009^{9)}$ ). (Kim and Kang 2012 $\left.{ }^{10}\right)$ Found that Smartphone Banking is continuously getting priority because smartphone users are expanding day by day. Smartphone banking is using a telephone or other mobile tool to comply obligations consisting of tracking account balances, transferring price range among bills, bill payment and finding an ATM whilst far from your private home laptop. In addition, smartphone banking services offer omnipresent services to clients. To improve the usefulness and more noteworthy dimensions of $3 \mathrm{G}$ mobile and its services require an inside and outside perception of users to improve smartphone banking services.

Novelty and curiosity concerning the use of smartphone banking services turned into referred to inside an investigation by way of a reason to choice of 
smartphone. The existing consequences reveal the reality in which smartphone banking services are at a rather primary level inside the route of diffusion. Its miles frequently the event of early adopters of advanced technological innovation is prompted without a doubt with the aid of the aspiration to progress their arms on the modern \& the finest novelty of the study; the stimulus is interesting vis-à-vis something this is truly state-of-the-art.

Smartphone banking services have not still long away outside of this segment, denoting really that Smartphone banking offerings aren't yet absolutely long-standing; they have not completely come to be a part of the continuing exercise \& manner of life of the adopters. Espousing mobile banking services in developing international locations, banks are confronted with tactical possibilities among the selection of shipping channels as well as the extent of refinement of offerings furnished by means of these transport channels (Ahmed and Islam, $2008^{11)}$ ). Banks will achieve the advantages of IT real with entirely if the simplest process to pay well by the customers needed enough attentiveness to technological advancement in addition to the aspects of production efficiency (Chandrasekhar and Sonar, 2008 ${ }^{12)}$ ).

\section{Consumer expectations from smartphone banking services}

Worldwide smartphone selection is set to increase incredibly in the coming years, especially in creating markets. As more non-banked buyers' access smartphone with Internet administrations, open new doors for mobile money-related service models would emerge. Basically, GSMA mentions that Mobile Money for the Unbanked (MMU) White Paper discussions about the identified factors to make a role and their importance of mobile cash expansion while clients' desire satisfaction is a key purpose of smartphone banking reception whereas customers' expectation fulfillment is a key point of Smartphone banking adoption.

Expectation Disconfirmation Hypothesis (EDT) could be a distinctive model within the customer behavior and promoting writing to clarify after uses feedback (Churchill and Suprenant, 1982 ${ }^{13)}$; Oliver, 1980 ${ }^{14)}$ ). Concurring to the EDT, the equal of disconfirmation concerning a utilization that touches the perception and client satisfaction (Oliver, 1980 ${ }^{14)}$ ). Once a consumer overwhelmed the product or services, in most cases, the expectation will decide the levels of satisfaction and future intention to repurchase. Afterward, expectation plays a vital part in utilization pattern (Bhattacherjee, 2001b ${ }^{15)}$; Bhattacherjee and Premkumar, 2004 ${ }^{16)}$ ) have utilized the desire to assess execution.

The study stands to pinpoint the key factors, which are mostly affecting the choice of Smartphone Banking Services.
(Devlin and Wright; 1995 ${ }^{17)}$ ) Found that within the service providing industry, particularly financial services are foremost changes carried approximately by advancements in data innovation include especially the interface between buyers and firms, the era of unused benefit items. Technological development could be a complex idea for different reasons, one of these being nonexclusive breadth of the concept itself. In truth, numerous sorts of innovation are appropriate to the concept. Innovation characterizes "the information of the control of nature for human purposes" (Betz, 1998 ${ }^{18)}$ ).

Smartphone Banking plays a noteworthy function in the reveal and fulfilling client demands of day to day banking functions (Hanafizadeh et al. 2014a $\mathrm{a}^{19)}$, and an additional study by Kim et al. $\left.2009^{9}\right)$. Customers regard 'Convenience' as the most distinguishing features of Smartphone banking service from conventional banking services since it offers quick access and easy procedure for users (Lee, 201120) From the security perspective, however, 'Convenience' from increased accessibility and simplified procedure of Banking service means rather susceptible environment to hacker attempts, which undermine the users' financial data (Park et al. 2011 ${ }^{21)}$ ).

(Susanto et al. 201522) ) Discovered that clients' authorization after the preliminary usage of the banking functions by using a smartphone has a noteworthy effect on trust, perceived usefulness, Perceived security, user satisfaction persuasively impacts on trust whereas perceived usefulness notably impacts on trust, user satisfaction, and intention of usage.

The Smartphone banking enterprise was established to an awesome scope than the former phase besides, grew exquisite photograph of their numerous spots along with digital banking. Now contemporary banking offerings have released by means of a few multinationals and new neighborhood private industrial banks. The very last phase inside the diffusion of an innovation is common to reuse, while innovation emerges as combined with normal actions of users (Rogers, 1983 ${ }^{23)}$ ). (Castiglione et al. 200924); A number of attack cases, e.g. Trojan, mobile phasing, key logger and MITM (Man in the middle) have been reported since the launching of the first Smartphone banking application. Security vendors now consider mobile banking service among the various mobile services as the highest security concern (McAfee report, 200925)).

\subsection{Scope of the study}

There's need to think regarding more studies on Smartphone based banking services (Kim, 2008 ${ }^{26)}$ ). Most of the current centered on e-commerce (Casaló et al. $2007^{27)}$ ) and the common e-banking context (Casaló et al. 200727), and Kim, 2008 ${ }^{26)}$ ). The study argued on the era of smartphone users manage an account which consists of few comfortable features including electronic banking and electronic commerce which means one of a kind highpoints, hence requiring amazing investigation the 
era.

Typically eCommerce transaction, managing the confidential information that is expounded to money which aspects. Subsequently, clients might have extra focus as getting smartphone-based banking services, whereas smartphone provides global conventional banking services, also offers higher facilities like privacy and security compared to a personal computer (PC) centered E-banking (Shaikh and Karjaluoto, 201528). In this manner, to fill the gap of the study and to help banks in understanding users' continuation of choice. The study focus on the investigation of factors influencing the choice of Smartphone Banking in Bangladesh.

\subsection{Smartphone banking services as a part of the knowledge economy in the frame of the new economy}

Smartphone banking can be treated as technological innovation because it allows customers to conduct banking transactions without constraints of time and place and to connect banking services easily and quickly with mobile devices (Laukkanen, 2007b ${ }^{29}$ ). Perceived usefulness (PU) and Perceived ease of use are of the strongest utilitarian determinants in the study of technology adoption, defined as the degree to which consumers believe in enhancing job performance by using a particular system or technology (Davis, 1989 $\left.{ }^{30}\right)$. M-banking (Mobile Banking), refer collectively to a set of applications that enable people to use their mobile telephones to manipulate their bank accounts, store value in an account linked to their handsets, transfer funds, or even access credit or insurance products (Karjaluoto, $2002^{31}$ ). M-banking (Mobile Banking) systems have all the markers of an 'innovation' waiting to be 'diffused' to or adopted by a subset of mobile users in the developing world (Rogers, $\left.1983^{23}\right)$.

If navigating a m-banking/m-payments interface is difficult for experienced mobile users with bank accounts, even greater is the difficulty for first-time users in the developing world, many of whom will have only been using a mobile for a year or so (Cracknell, 2004 ${ }^{32}$ ); Peevers et al. 2008 ${ }^{33)}$ ). Smartphone banking/m-payments systems in the developing world are also scarce because the systems are very new to the customers. The best impact assessment to date is (Porteous, 2007 ${ }^{34}$ ), in which impact is operated using an 'access frontier', which divides those who have the wherewithal (a monthly income from a formal source) to open the most basic of conventional bank accounts. However, there is room for more work that assesses which forms of trust are supported by m-banking/m-payments use, particularly among low-income users.

(Oliner and Sichel, 2000 ${ }^{35)}$ ) Determined that Information and Communication Technologies (ICT) are the mainstay of the knowledge grounded economy and in current years were identified as a powerful device for promoting economic growth and sustainable progress. With extraordinarily fewer usage prices and the potential to conquer distance, ICT has modernized the transformation of information and knowledge around the world. During the past decade, it can be found that a series of research shows that both ICT manufacturing and ICT utilize to have a great contribution to the economic boom of a country. Consumers within the growing global, but the enchantment of these m-banking/ m-bills systems could be much less comfortable and greater accessibility and affordability (Cracknell, $\left.2004^{32}\right)$.

The professionals' reviews concerning the definition of the knowledge-based economy or the new economic system are distinctive from one to every other. (Archibugi and Lundvall, 2001 ${ }^{36)}$ ) "The Globalizing Learning Economy" method indicates the new economy since the inception of enlightening society and globalization whereas the latest economic process as "an economy greater dominated with the aid of the worldwide impacts and by means of the velocity, often at present, the communications and fact, no substance what the distance. Now a day's smartphone-based banking services are creating a landscape of the economic contribution of a country and technology-based economy.

Financial organizations, which have had trouble to provide profitable offerings over traditional channels to least profitable customers, perceive m-banking/m-payments as a shape of 'branchless banking' (Ivatury, 2004 ${ }^{38)}$ ) which also reduce the costs of less profitable customers. (Solow, 1957 ${ }^{39)}$ ) \& (Romer, $1990^{40)}$ ) cited that the theory of economy shows that the advancement of technology is the main source of productivity expansion and a powerful innovation instrument is prime for such technical growth. Numerous new and complicated functions had delivered in smartphones to make ease of the clients' way of life and to make consumer lifestyles simpler.

\section{Requirements of Smartphone Banking services choice}

Bangladesh is a country about 161 million people with an overwhelmingly large size in population. According to the World Fact book, over $65 \%$ of the Bangladeshi population is under the age of 35 . In addition to this, in 2017, the number of mobile phone subscribers reached 131.98 million people. Each year as more and more people migrate to more affordable and more powerful phones. In the present, smartphones become cheaper, thus the number of smartphone users in the country is increasing, as well as the number of mobile app users. Bangladesh is a country with the vast future prospect of the smartphone market.

Based on the literature of earlier studies, focus group discussion and expert interview; researchers are enabled to identify the factors that are affecting to measure the customers' choice of Smartphone Banking Services in Bangladesh that are Cost, Network and Smartphone, 
Confidentiality, Perceived Privacy and Security, Perceived Convenience, Perceived Financial cost, Reliability and Trust, Perceived Convenience are typically upsetting the choice of Smartphone Banking services.

\subsection{Perceived privacy and security}

Requirements for choice in smartphone banking services with the perspective of security aspect can be drawn from the security requirements in the e-Banking service context. Authentication of smartphone banking service should satisfy the fundamental security requirements for electronic financial transactions that are protecting user's financial data from hacker's attack and prevent forgery of confidential data (Lee et al. 2010 ${ }^{41)}$ ).

According to ISO 2002 (ISO 7498-2) and several researchers, fundamental security requirements for electronic financial transactions (via internet and mobile) are classified into (user/server) access authority management, (communication channel) confidentiality, integrity, (transaction data) non-repudiation (Hanaeek et al. 2008 ${ }^{42)}$ ) that is, the method must not give away critical information and alter transaction information in response to malware and phishing so that the attackers could not use the information they obtained. The server must grant information only to authorized users and prevents reading, piracy, and transformation by illegal subjects and it must provide non-repudiation to prevent transaction and exchanged data at wrong transaction and error event (Hanaeek et al. 2008 ${ }^{42)}$ ).

Banks requisite to directly speak of the troubles of Privacy and Security issues in net banking since they're the primary factors which are prominent to a huge range of persons who are nevertheless unenthusiastic to exploit internet-based banking services (Pikkarainen et al. $2004^{43)}$ ). The literature also confirmed that the notion of web safety influences customers' attitude towards banking by the mobile device (Cheng et al., 2006 ${ }^{44)}$ ), and

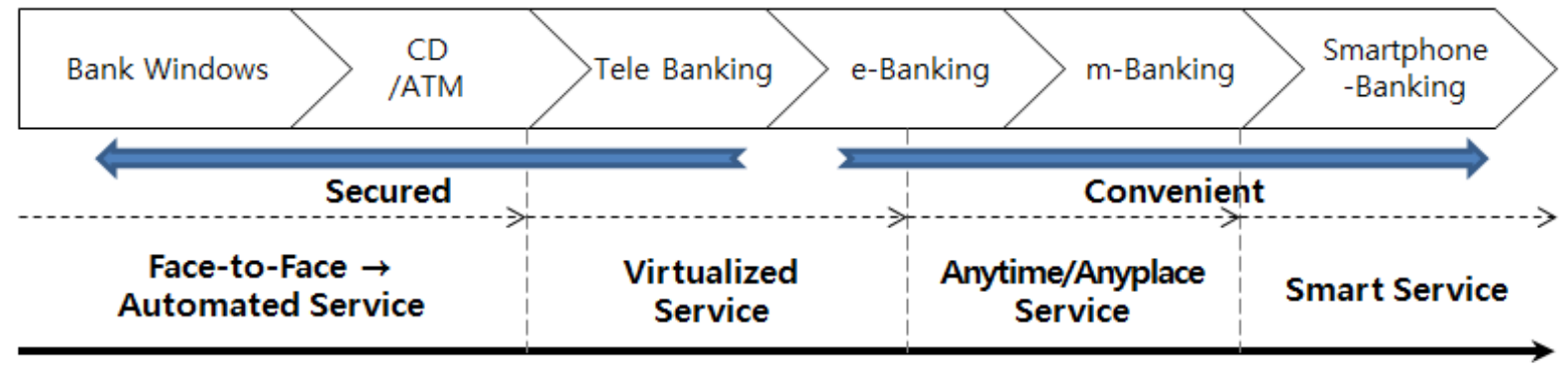

\section{Expansion of Banking Channel}

Fig. 1: Evolution of Smartphone Banking (Adapted from (Keon Chul Park et al. 2012 ${ }^{37)}$ )

shortage of Privacy and Security decline clients' pleasure and trustworthiness inside the milieu of smartphone banking functions (Chen, 2012 ${ }^{45)}$ ). Table 1 shows the key points of privacy and security aspect.

Table 1: Essence of privacy and security evaluation.

\begin{tabular}{|l|l|}
\hline Requirements & Definition \\
\hline $\begin{array}{l}\text { Authority } \\
\text { Management }\end{array}$ & $\begin{array}{l}\text { Identify and authenticate } \\
\text { legitimate users when providing } \\
\text { Electronic financial transaction }\end{array}$ \\
\hline Integrity & $\begin{array}{l}\text { Confirm the forgery of electronic } \\
\text { financial transaction data }\end{array}$ \\
\hline Non-Repudiation & $\begin{array}{l}\text { Provide proper electronic } \\
\text { financial transaction the fact that } \\
\text { users and financial institutions } \\
\text { cannot deny }\end{array}$ \\
\hline $\begin{array}{l}\text { Adapted from (Hanaeek et al. 2008 } \\
\left.2010^{41)}\right) .\end{array}$
\end{tabular}

\subsection{Perceived convenience}

Overview of smartphone banking service results in a more convenient way to acquire financial service than the existing conventional service since it provides anytime, anyplace service with increased accessibility, mobility, and availability (Laukkanen, 200746)); also by (Pura, 2005 ${ }^{47)}$ ). However, the intense emphasis on security aspect might violate convenience, so there is a need to derive an authentication method consisting of appropriate harmony between security and convenience. Any inconvenience of usage from the strengthening process of security would reduce the user preference no matter how secure the authentication method (Lim et al. $2008^{48)}$ ). Arguments with the obligatory use of Public Key Certificate for Smartphone banking in Korea have been occurred due to the complexity of use, proceeding speed, compatibility issues which bear tremendous of inconvenience to users (Kim et al. 2010 ${ }^{49}$ ). The features of perceived convenience are shown in Table 2.

Table 2: Requirements of convenience aspect.

\begin{tabular}{|l|l|}
\hline Requirements & Definition \\
\hline
\end{tabular}




\begin{tabular}{|l|l|}
\hline Compatibility & $\begin{array}{l}\text { Supports various OS and maintain } \\
\text { neutrality on technology (platform, } \\
\text { device) }\end{array}$ \\
\hline Ease of use & $\begin{array}{l}\text { Convenience in program installation } \\
\text { to use authentication mechanism, } \\
\text { easily identify the authentication } \\
\text { mechanism }\end{array}$ \\
\hline $\begin{array}{l}\text { Processing } \\
\text { speed }\end{array}$ & $\begin{array}{l}\text { Quick response in authentication } \\
\text { processing and provide real-time } \\
\text { service }\end{array}$ \\
\hline Portability & $\begin{array}{l}\text { No burden/inconvenience in carrying } \\
\text { authentication token/ method }\end{array}$ \\
\hline $\begin{array}{l}\text { Issuing } \\
\text { easiness }\end{array}$ & $\begin{array}{l}\text { Provide simple and easy procedure } \\
\text { when issuing new authentication or } \\
\text { reissuing authentication }\end{array}$ \\
\hline $\begin{array}{l}\text { Adapted from } \\
\text { and (Lee, 2011 }\end{array}$ \\
\hline
\end{tabular}

\subsection{Perceived financial cost}

Businesses' economic burden such as system setup costs and user program setup would be major standards in selecting authentication alternatives (Dube et al. $2009^{50)}$ ). In terms of users' economic burden, there are electronic banking transaction like terminal-of-pocket costs and network interconnection costs and authentication setup costs like cost of issuing new authentication and renewal cost (Sergios and Nikolaos, $2010^{51)}$ ).

(Hwang, 2010 ${ }^{52)}$ ) Pointed that apart from security and convenience when introducing authentication method cost is an essential factor for the users. Costs in relation to authentication mechanism are in two terms: service provider's implementing costs for system setup for Smartphone banking authentication and users' purchasing or issuing costs for authenticated users. No matter how secure and convenient the authentication is, high-price to use would mean falling of the user's preference (Lim et al. 2008 ${ }^{48}$ ). As users' major choice of electronic banking transaction is by economic ones like saving service fees and cost, and service non-choice or by the financial burden to service use, the authentication method for Smartphone banking must be made to guarantee to minimize users' economic burden.

Table 3: Requirements in Perceived Financial Cost aspect.

\begin{tabular}{|l|l|}
\hline \multicolumn{1}{|c|}{ Requirements } & \multicolumn{1}{|c|}{ Definition } \\
\hline $\begin{array}{l}\text { Implementation } \\
\text { Cost }\end{array}$ & $\begin{array}{l}\text { Businesses' economic burden such } \\
\text { as system setup costs and user } \\
\text { program setup }\end{array}$ \\
\hline
\end{tabular}

\begin{tabular}{|c|c|}
\hline Issuing Cost & $\begin{array}{l}\text { Terminal-of-pocket costs and } \\
\text { network interconnection costs and } \\
\text { authentication setup costs like the } \\
\text { cost of issuing new authentication } \\
\text { and renewal cost }\end{array}$ \\
\hline & \\
\hline
\end{tabular}

\subsection{Reliability and trust}

Trust includes three inborn building elements of trustworthiness: initially, the trustee's capacity, which is a lot of abilities and skills to play out one's targets; secondly consideration that is the level of glowing sense plans vis-à-vis others; and thirdly, honesty, which is the fixed standards of confiding in others (Luarn and Lin, $2005^{53)}$ ). An additional study by (Mayer et al. $1995^{54)}$ ) Characterized trust as the eagerness of a gathering to be powerless against the activities of another gathering dependent on the desire which can play out a specific activity vital to the trust, regardless of the capacity to screen or regulator that is also considered as additional gathering.

The challenge for the Chief Data Officers (CIOs) and Chief Specialized Officers (CTOs) of banks try to cover the areas smartphone banking framework to control the exponential expansion of clients. Moreover; Reliability and Thrust are interconnected of smartphone banking whereas smartphone banking clients might be active in any corner of the globe (anytime, anyplace banking) and banks ought to guarantee that frameworks are upgraded and 24 hours true services $(24 \times 7)$ fashion. Banks are not always enabled to meet the expectation of the client's execution, reliability if the banks are not able to provide services properly that creates perception lost means loss of the thrust of clients. In outline, the scope of trust may differ as it depends on the connections, experience, advanced stages, and signs in the surviving condition (Rousseau et al. 1998 ${ }^{55)}$ ).

\subsection{Behavioral Intention}

Given that a definitive objective of organizations (i.e. banks) stands to pull in clients to choose the services instead of the expectation of adoption with banking services, wide-ranging research has inspected the connection between the intention of the users and actual services. Though, a single effort in surviving mobile banking examines has brought this connection into the investigation procedure (Sripalawat et al. 2011 ${ }^{56}$ ), which urges a need to look at the connection between social expectation as well as actual performance in versatile mobile banking background.

Above these analyses regarding the choice of smartphone-based banking functions to the bank clients those who are like to use modern technology (smartphone) in banking services, the customers' consider some key factors. From the literature, the 
researchers' constructed an innovative model to identify the factors, which indicated the choice requirements of smartphone banking.

This proposed model indicates that customers' are the focused point and their expectation regarding the smartphone banking services key factors are Perceived Financial Cost, Network and Smartphone, Confidentiality, Privacy and Security, Reliability, Trust, and Perceived Convenience is most important to choose of Smartphone banking. Analyses to the choice of smartphone banking services of bank clients' those who are like to use a modern technological device like a smartphone in banking services, the customers' consider some key factors. From the literature, the researchers' constructed an innovative model to pinpoint the factors, which are influencing the adoption of smartphone banking showed in Fig. 2.

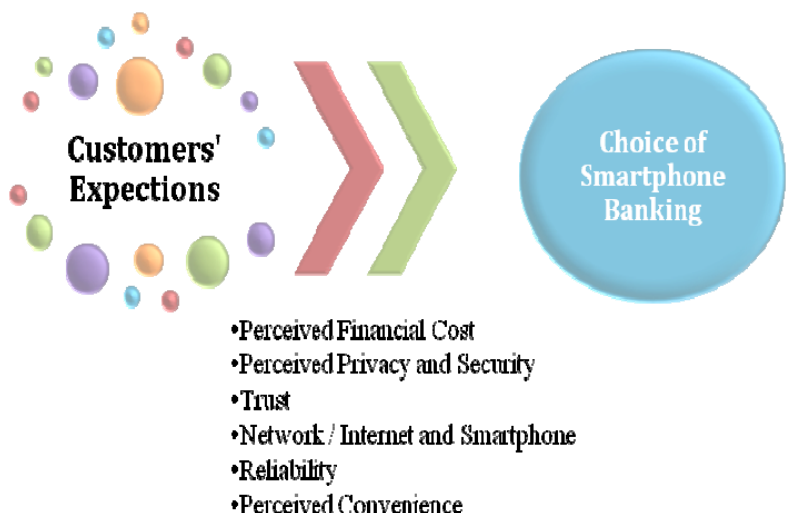

Fig. 2: Conceptual Framework

\section{Method of the Study}

To measure the customer expectation regarding the choice of smartphone banking at the first stage, an exploratory investigation is conducted to identify the factors affecting to determine the choice of Smartphone Banking Services in Bangladesh. Then descriptive research is conducted which is, reveals to wondering study, as it requires some analysis on the determinants' of the choice of smartphone banking services. In choosing the sample for the qualitative interviews, researchers made efforts to ensure variety by interviewing bank account holders like general and corporate account holders. If the respondents concurred at that argument they continued to reply to a 15 -minute overview.

A total of 180 individual smartphone bank account holders were surveyed through standardize questions. The structured questions have open-ended and close-ended questions with the measurement using 5 (five) point Likert scale. The primary data are collected by this study used depth interview by a structured survey from both genders of smartphone users who are bank account holders like a general customer and corporate customers' of banks in the period of June to September of 2018. This study used a frequency distribution to measure which factors are more important to smartphone banking. Moreover, multiple regression analysis also conducted to find out the variables, which are most influences of smartphone banking choice to the clients.

\section{Results and discussion}

A frequency distribution is also conducted to measure the demographic part of the respondents how it influences to identify the factors of choice of smartphone banking services.

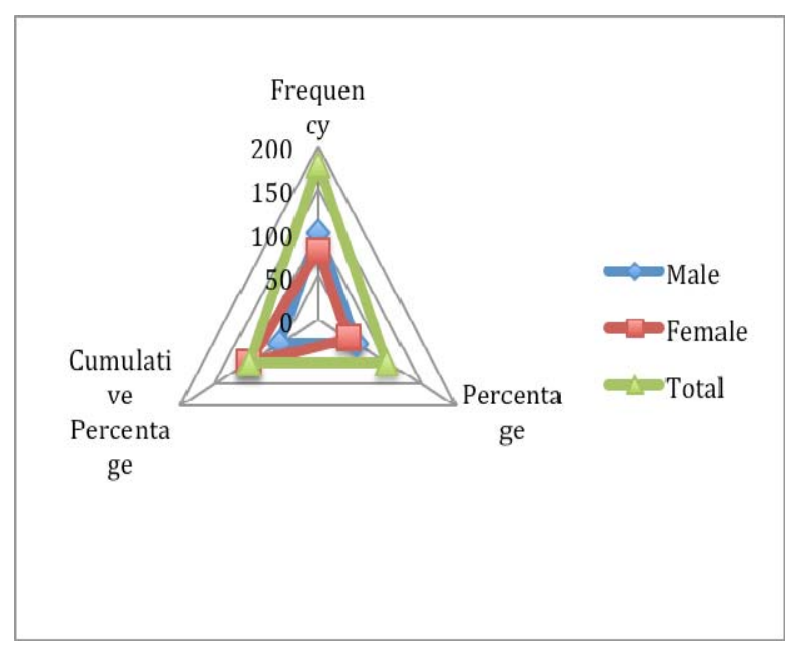

Fig. 3: Gender of the Respondents.

From 180 respondents, 56\% respondents' are male and $44 \%$ are female but mostly the male has given their main opinion for the choice of Smartphone banking about the security of Smartphone banking, on the other hand, most of the female has given their opinion on convenience. Relatively males are more interested in Smartphone banking than females. Most of the male think that that security and reliability is more important for the choice of smartphone banking, but most of the female thought that's easy to use is more essentials of smartphone banking adoption.

It is earnest to note that from Fig. 4 the frequency of respondents age in which shows that a majority of $56 \%$ respondents at the age of 21-30 years old and second majority respondents are $22 \%$ at the age of $31-40$ years old because most of the young generations are used to smartphone that's why they are operating their banking activities with smartphone to save the time.

Furthermore, Fig. 5 shows that the respondent's occupation level. In this study, data are collected from a different category of respondents, whereas $50 \%$ of respondents are service holders and $22 \%$ of respondents' are the businessman as well as $17 \%$ of respondents are students. Most of the service holders are preferred to security; the cost of services but the students' are concerned about the cost and convenience factors to the authentication of smartphone banking. Senior citizens are 
considered the convenience, and reliability is important of smartphone banking services adoption.

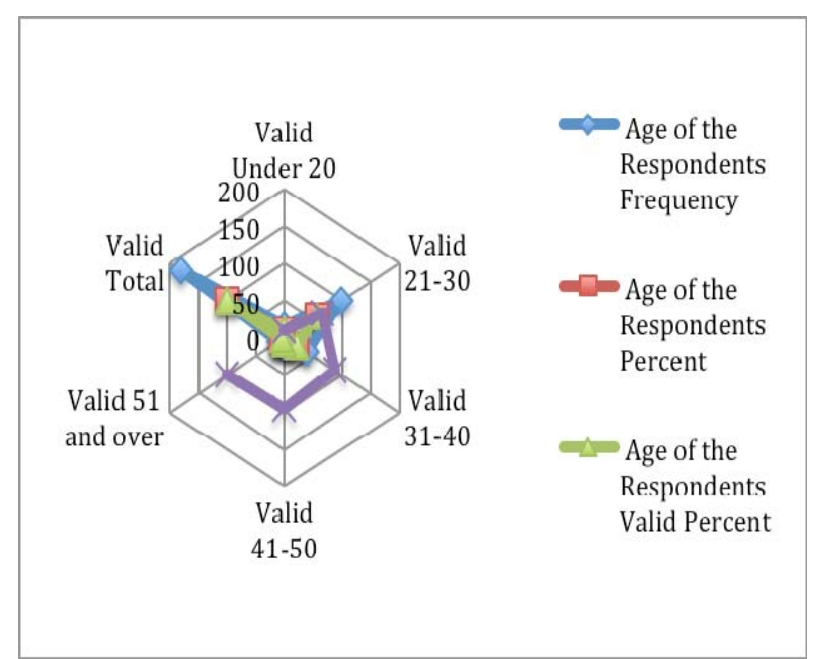

Fig. 4: Respondents Age Pattern.

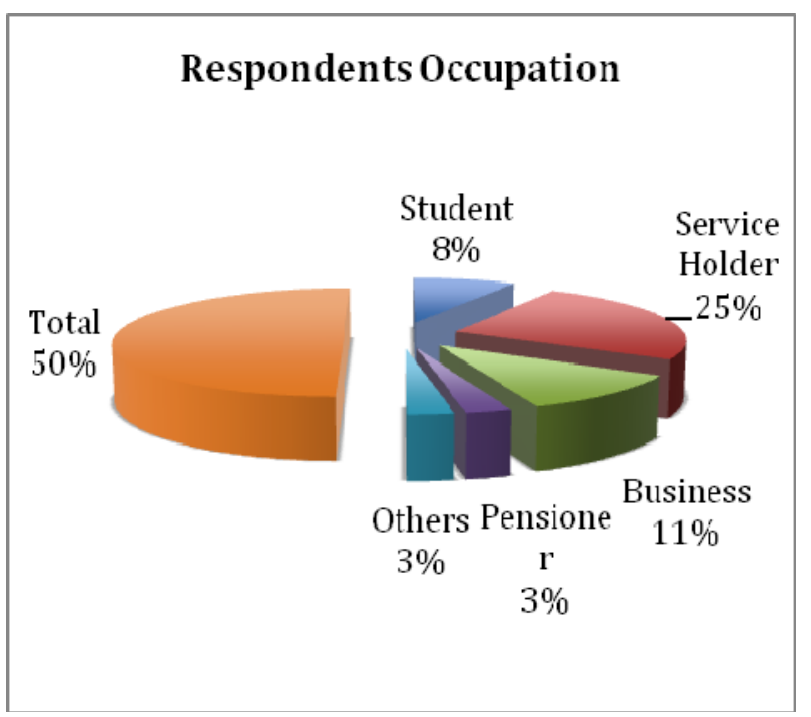

Fig. 5: Respondents Occupation Level.

But, smartphone banking services authentication varies on the income level of the clients' of a particular country and the users of the smartphone but income and the smartphone users are interconnected.

Table 4: Respondents Income Level.

\begin{tabular}{|c|c|c|c|c|}
\hline Incor & Level & 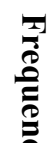 & 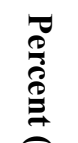 & 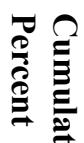 \\
\hline & Less than Tk 15000 & 15 & 8.0 & 8.0 \\
\hline & Tk15000-30000 & 80 & 44.4 & 52.4 \\
\hline & Tk30001-45000 & 40 & 22.0 & 74.4 \\
\hline & Tk45001-60000 & 30 & 17.0 & 91.4 \\
\hline
\end{tabular}

\begin{tabular}{|l|l|l|l|l|}
\hline & 60001 and over & 15 & 8.33 & 100.0 \\
\cline { 2 - 5 } & Total & 180 & 100.0 & \\
\hline
\end{tabular}

Firstly majorities $44 \%$ of smartphone banking services customers income level category is 15000-30000 basically they are minimum average wages group or newly appointed in jobholders or young businessman. Respondents preferred that convenience and Smartphone with the best network, but the second majority income category $30001-45000$, in which $22 \%$ are preferred cost, security, and reliability. Mostly high range of income group is mostly preferred the smartphone banking services because of convenience, and reliable.

Education level also impacts the choice of smartphone banking services; data show that the majority of smartphone banking customers' education level is Bachelor. A second majority represents the customers' are Master's degree holders. Education levels of SSC and HSC level of respondents are not much more interested in smartphone banking rather they like to traditional banking system.

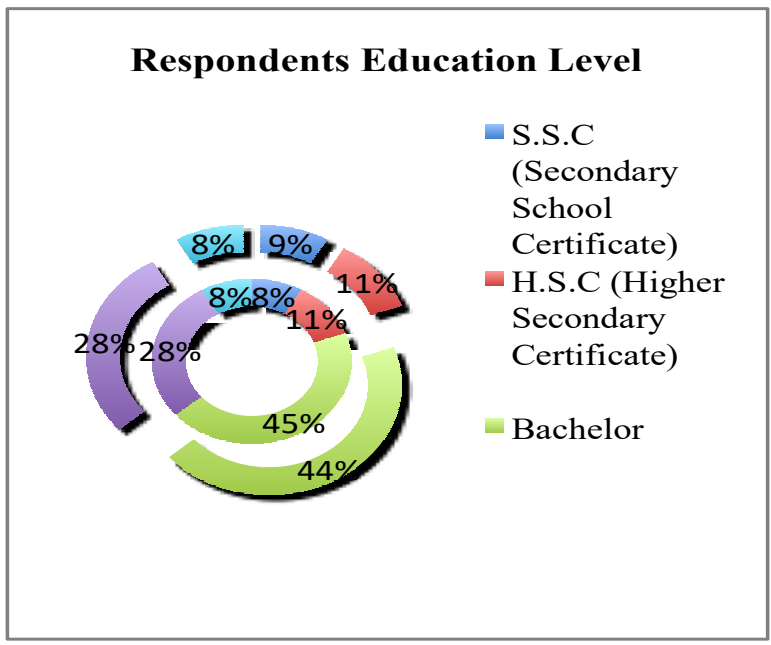

Fig. 6: Respondents Education Level.

\subsection{Results of Multiple regressions and hypothesis test}

To reveal additional assists as hypothesis testing and multiple regressions evaluation performed to check the cause and effect relationship between the identified variables of the study. The Multiple regression procedure does stay devoted because it provided the almost perfect amount on the critical factors, then such helps in conformity with check whether the identified variables that will help to assess whether the identified variables, i.e. Privacy and Security, Perceived Convenience, Perceived Financial Cost, Reliability and Trust are exerted a significant influence on smartphone banking services.

Ho: Privacy and Security, Perceived Convenience, 
Perceived Financial Cost, Reliability and Trust are significant of Smartphone Banking Services adoption.

H1: Privacy and Security, Perceived Convenience, Perceived Financial Cost, Reliability and Trust are not significant of Smartphone Banking Services adoption.

The determination of this investigation is to measure the degree of the relative influence of factors to the choice of Smartphone Banking services in which the independent variables are summarized: Privacy and Security, Perceived Convenience, Perceived Financial Cost, Reliability and Trust, and Network and Smartphone.

The regression model can be written as follows

$$
\begin{aligned}
Y=b_{0}+b_{1} S P & +b_{2} C n+b_{3} C o+b_{4} T h+b_{5} R e \\
& +b_{6} N \& S p+e i
\end{aligned}
$$

Where, Y-Choice of Smartphone Banking Services; SP -Security and Privacy; $\mathrm{Cn}$ - Perceived Convenience; Co - Perceived Financial Cost; Th - Trust; Re - Reliability; N\&Sp - Network and Smartphone; ei - Error.

Table 5: Model Summary

\begin{tabular}{|l|c|l|c|c|}
\hline \multicolumn{5}{|c|}{ Model Summary } \\
\hline Model & $\mathrm{R}$ & $\begin{array}{l}\mathrm{R} \\
\text { Square }\end{array}$ & Adjusted & Model \\
\hline 1 & $0.80 \mathrm{a}$ & 0.689 & 0.606 & 0.339 \\
\hline $\begin{array}{l}\text { a. Predictors: (Constant) Privacy and Security, } \\
\text { Perceived Convenience, Perceived Financial Cost, } \\
\text { Reliability and Trust, and Network and Smartphone. }\end{array}$ \\
\hline \multicolumn{4}{|l}{ Source: Own data } \\
\hline
\end{tabular}

\subsection{Findings of the study}

The Value of $\mathrm{R}=0.80$, it demonstrates a high degree of a positive association between the autonomous and subordinate factors of this study. The value of $\mathrm{R} 2=0.689$, it too appears that $69 \%$ variation within the subordinate factor is the fittest for the examination. Balanced R2 value 0.606 or nearly $61 \%$, which shows that expansion of the autonomous factors, don't make a commitment to clarify the variety within the subordinate variables.

The result of ANOVA shows that the coefficients of the study, whereas Choice of Smartphone Banking = $1.532+.832$ (Privacy and Security) $+(-.326)$ (Perceived Convenience) $+(-.052)$ (Reliability) +.002 (Perceived Financial Cost $)+(-.219)$ (Trust) +.725 (Network and Smartphone) from this equation, it's found that the validation of Smartphone Banking depends on various dimensions like - Privacy and Security, Perceived Convenience, Perceived Financial Cost, Trust, Reliability, Network, and Smartphone but all are not similar importance in the choice of Smartphone Banking Services. The study found that Privacy and Security (0.001), Network and Smartphone (0.003), Perceived
Financial Cost (0.02), Perceived Convenience (0.052) and Trust (0.05) are highly significant to choice smartphone services by the bank account holders, but in case of reliability (.56) which is not significant that means the second priority of bank account holders. Above dialog indicates that the identified all the factors are significant except reliability to make a preference of Smartphone Banking that's why the results of hypotheses indicated that null hypothesis is accepted and the rejection of the alternative hypothesis.

\section{Conclusions}

The smartphone has turned into a more public and multipurpose device; it may perform a vital part to make connections amongst clients and finance related service suppliers, retail outlet, and other businesses. Today continuous existence of mobile phones to finish day to day activities and makes their life more easier and providing useful financial data in timely which help to assist in the decision making the process.

To enlarge the monetary financing in the area of smartphone-based banking services, the service organization's i.e. banks must promise that customers will remain to usage required services later the preliminary involvement.

The study is trying to identify the factors that are influenced to make a choice of smartphone banking services. Such exercises upgrade clients' fulfillment and believe in exploiting and managing banking functions perpetually (Susanto et al. 2015 2 ). Besides, Banking Services traits have a particular area such as imperceptibility and complication, which display maximum stages of instability and complexity. Banking forms must dispatch primitive promotions to preserve client believe and create a Trustworthy relationship.

Managerial implications of investigation refer to smartphone user satisfaction may be a key component to extend continuation utilizes intention in financial services. Hence, in Bangladesh banks ought to progress client fulfillment with satisfying client needs and perquisites through effective reactions. But, the theoretical implication of the study has shown a conceptual framework for smartphone banking which will be a powerful support to get an insight of researchers in further investigations.

In this study, it was confirmed that Financial Cost, Perceived Security and Privacy, Convenience, and Network/Internet facilities are the significant factors which are influencing the choice of Smartphone Banking Services. Reliability risk has an adverse influence on the validation to use both account check and account transfer, and the degree of negative effect was greater in account transfer. (Kimura, 2017 $7^{57)}$ ) study on 'social and business' investigation recommended that promote social inclusion, upholding environment conservation, maintain business feasibility and others are essentials to grow the market economy. 
The customer also expected that in account check and other transaction authentication factors are having the greatest effect of the perception of bank account holders, while security is the factor with the greatest effect on smartphone banking. In Bangladesh, Financial organizations are recently restarted banking with a smartphone that's why smartphone banking becomes in one hand within the market. Large provision of banking and finance related functional services with the help of cell phone. This policy is moving to propose with notably shared smartphone applications which meet the requirements of $21^{\text {st }}$-century customers.

\section{References}

1) S. Alwahaishi, and V. Snášel. $3^{\text {rd }}$ Intl. Conference on Digital Information and Communication Technology (DICTAP2013), 31 (2013).

2) G. Carayannis, and S.C. Clark. Journal Knowledge Economy, 2, 201 (2011).

3) A. J. Rohm, T. T. Gao, F. Sultan, and M. Pagani, Journal Business Horizons, 55, 485 (2012).

4) H. Chun, H. Lee, and D. Kim, Journal Cyber psychology, Behavior, and Social Networking, 15, 473 (2012).

5) S. M. Goldman. Journal Consumer Marketing, 27, 469 (2010).

6) B. Saddik, Bara D. kah, and B. Aldosari, $6^{\text {th }}$ Intl. Symp. of Medical Information and Communication Technology (IICT), 1 (2012).

7) M. Kenney, and B. Pon, Journal Industry, Competition and Trade, 11, 239 (2011).

8) H. Dai, H., P.C. Vand Palvi, ACM SIGMIS Database, 40, 43 (2009).

9) G. Kim, B. Shin, and H.G. Lee, Information Systems, 19 (3), 283 (2009).

10) J.B. Kim, J.B. and S. Kang, Intl. Journal Multimedia and Ubiquitous Engineering, 7 (3), 87 (2012).

11) F. Ahmed, and T. Islam, Business Review, 06 (1\&2) 168 (2008).

12) M. Chandrasekhar and Sonar, Rajendra M. South Asian Journal of Management, 15 (3), 74 (2008).

13) G.A. Churchill, and C. Surprenant, Journal Marketing Research, 19 (4), 491 (1982).

14) R.L. Oliver, Journal Marketing Research, 17 (4), 460 (1980).

15) A. Bhattacherjee, MIS Quarterly, 25 (3), 351 (2001b).

16) A. Bhattacherjee, and G. Premkumar, MIS Quarterly, 28 (2), 229 (2004).

17) J.F. Devlin J.F. and M. Wright, Marketing Financial
Services. Butterworth-Heinemann: Oxford (1995).

18) F. Betz, John Wiley \& Son: New York (1998).

19) P. Hanafizadeh, B.W. Keating, and H.R. Khedmatgozar, Telematics and Informatics, 31 (3), 492 (2014a).

20) S.M. Lee, Information Technology \& e-Commerce, 46, 31 (2011).

21) K.C. Park, S.J. Kim, and B.G. Lee, 6th Intl. Conference on Ubiquitous Information Technologies \& Applications, Korea, 177 (2011).

22) A. Susanto, Y. Chang, Y. Ha, Industrial Management and Data Systems, 116 (3), 508 (2015).

23) E.M. Rogers, 'Diffusion of innovations' (3 ${ }^{\text {rd }}$ ed.). New York: The Free Press (1983).

24) A. Castiglione, R.D. Prisco, and A. De Santis, EC-Web 2009, LNCS 5692, pp. 50-61 (2009).

25) McAfee, "Mobile security reports" http://www.mcafee.com/us/resources/reports (2009). Accessed 15 December 2018.

26) S.H. Kim, Information \& Management, 45 (6) 387 (2008).

27) L.V. Casaló, C. Flavián, and M. Guinalíu, Online Information Review, 31(5), 583 (2007).

28) Shaikh, A.A. and Karjaluoto, H. "Mobile Banking Adoption: a literature review", Telematics and Informatics, Vol. 32 No. 1, 129-142 (2015).

29) T. Laukkanen, Intl. Journal of Mobile Communications, Vol. 5(2), 123 (2007b).

30) F.D. Davis, MIS Quarterly, Vol. 13(3), 319, (1989).

31) H. Karjaluoto, International Journal of Retail \& Distribution Management, Vol. 30, 331 (2002).

32) D. Cracknell, Small Enterprise Development, 15, 8 (2004).

33) G. Peevers, G. Douglas, \& M.A. Jack, Intl. Journal of Human-Computer Studies, 66, 113 (2008).

34) D. Porteous, Just how transformational is m-banking? Retrieved 10 January 2008 (adapted http://www.finmarktrust.org.za/accessfrontier/Docu ments/transformational_mbanking.pdf (2007).

35) D. S. Oliner, and E. D. Sichel, Journal of Economic Perspectives. 14 (4), 3 (2000).

36) D. Archibugi, B.A. Lundval, "The Globalizing Learning Economy", Oxford University Press, Oxford, 21 (2001).

37) K.C. Park, J.W. Shin, B.G. Lee, KSII Transactions on Internet and Information Systems 8 (6), 2087 (2012).

38) G. Ivatury, Small Enterprise Development, 15, 25 
(2004).

39) R.M. Solow, Review of Economics and Statistics. 39, 312 (1957).

40) M.P. Romer, Carnegie-Rochester Conference Series on Public Policy. 32, 251 (1990).

41) B.G. Lee, Y.K. Yeo, K.Y. Kim, and J.H. Lee, The KIPS Transations: Part D, 16 (6), 471 (2010).

42) P. Hanaeek, K. Malinka, and J. Schafer, In Proc. of IEEE International Carnahan Conference on Security Technology, 326 (2008).

43) T. Pikkarainen, K. Pikkarainen, H. Karjaluoto, and S. Pahnila, Internet Research, 14 (3), 224 (2004).

44) T.C.E. Cheng, D.Y.C. Lam, and A.C.L. Yeung, Decision Support Systems, 42 (3), 1558 (2006).

45) S.C. Chen, International Journal of Mobile Communications, 10 (5), 490 (2012).

46) T. Laukkanen, Business Process Management Journal, 13(6), 788 (2007).

47) M. Pura, Managing Service Quality, 15 (6), 509 (2005).

48) J.H. Lim, H.W. Shim, S.H. Seo, and W.J. Kang, Korea Institutes of Information Security and Cryptology, 18 (5), 84 (2008).

49) H. Kim, J.H. Huh, and R. Anderson, Oxford University Computing Laboratory, CS-RP-10 (01), University of OXFORD (2010).

50) T. Dube, T. Chitura, and L. Runyowa, Journal of Internet Banking and Commerce, 14 (1), 1 (2009).

51) D. Sergios, and K. Nikolaos, Psychology \& Marketing, 27 (8), 799 (2010).

52) S.C. Hwang, Information Technology \& e-Commerce, 39, 29 (2010).

53) P. Luarn, and H.H. Lin, Computers in Human Behavior, 21 (6), 873 (2005).

54) R. C. Mayer, J.H. Davis, and F.D. Schoorman, Academy of Management Review, 20 (3), 709 (1995).

55) D.M. Rousseau, S. Sitkin, R.S. Burt, and C. Camerer, Academy of Management Review, 23 (3), 393 (1998).

56) J. Sripalawat, A. Thongmak, and A. Ngramyarn, Journal of Computer Information Systems, 51(3), 67 (2011).

57) R. Kimura, Evergreen Joint Journal of Novel Carbon Resources Sciences \& Green Asia Strategy, 04 (02/03), 38 (2017). 